\title{
PENGARUH MODEL PEMBELAJARAN KOOPERATIF TIPE TEAM ASSISTED INDIVIDUALIZATION DAN JIGSAW TERHADAP KEMAMPUAN PEMECAHAN MASALAH MATEMATIK SISWA MTS PADA POKOK BAHASAN RELASI DAN FUNGSI
}

\author{
Taufiqullah Dahlan \\ Program Studi PGSD \\ FKIP Universitas Pasundan \\ taufiqulloh@unpas.ac.id
}

\begin{abstract}
Abstrak: Penelitian ini berawal dari realita dilapangan bahwa banyak sekali model pembelajaran yang digunakan di sekolah. Serta masih kurangnya kemampuan pemecahan masalah ditingkat MTs. Oleh karena itu, penelitian ini bermaksud membandingkan dua buah model pembelajaran kooperatif tipe team assisted individualization dan model pembelajaran kooperatif tipe jigsaw. Kemampuan yang akan dijadikan pembandingnya adalah kemampuan pemecahan masalah. Tujuan penelitian ini yaitu untuk mengetahui perbedaan kemampuan pemecahan masalah matematika siswa yang menggunakan model pembelajaran kooperatif tipe TAI dan jigsaw. Selain itu, untuk mengetahui sikap siswa terhadap kedua model tersebut. Penelitian ini dilakukan di kelas VIII satu diantara MTs yang ada di Kabupaten Sumedang pada pokok bahasan relasi dan fungsi. Peneliti mengambil populasi seluruh siswa kelas VIII. Pengambilan sampel menggunakan teknik simpel random sampling. Hasil penelitian menunjukkkan bahwa kemampuan pemecahan masalah matematika siswa yang menggunakan model pembelajaran kooperatif tipe TAI lebih baik dengan nilai rata-rata 76,23 yang kedua model pembelajaran kooperatif tipe jigsaw dengan nilai rata-rata 75,57 dan yang terakhir model pembelajaran konvensional dengan nilai rata-rata 65. Oleh karena itu, dapat disimpulkan bahwa terdapat perbedaan kemampuan pemecahan masalah matematika siswa yang menggunakan model pembelajaran kooperatif tipe TAI, Jigsaw dan Konvensional. Untuk melihat perbedaan tersebut digunakan pengolahan data ANOVA satu jalur.

Kata Kunci-team assisted inividualization, jigsaw, dan pemecahan masalah matematis
\end{abstract}

\section{A. PENDAHULUAN}

Perkembangan pengetahuan dan teknologi yang menopang perkembangan budaya dan kehidupan manusia diberbagai belahan dunia sejak masa lalu, kini, dan masa yang akan datang dipengaruhi oleh kemajuan dalam bidang matematika. Oleh karena itu wajar apabila pada materi-materi pelajaran ditingkat sekolah konsep-konsep matematika melekat pada berbagai pelajaran, seperti pelajaran geografi, fisika, kimia, biologi, dan ekonomi, sehinggapenguasaan konep-konsep matematika merupakan penunjang untuk dapat memahami dan mengembangkan cabang ilmu lainnya.

Tidak dapat dipungkiri bahwa dalam hidup seseorang akan senantiasa bertemu dengan matematika, baik itu dalam pembelajaran formal, non formal maupun dalam kehidupan praktis sehari-hari. Matematika merupakan alat bantu kehidupan dan pelayan bagi ilmu-ilmu yang lainnya, seperti fisika, 
kimia, biologi, astronomi, teknik, ekonomi, farmasi maupun matematika itu sendiri, maka dari itu pembelajaran matematika sangatlah penting.

Mengingat pentingnya pembelajaran matematika, sangatlah memprihatinkan melihat kenyataan bahwa prestasi matematika di Indonesia baik secara nasional maupun international belum menggembirakan. Kualitas yang dicapai dalam pendidikan matematika dan sains di Indonesia masih berada di level bawah. Setidaknya itu tercermin dari hasil tes Trend in International Mathematics and Sciences Study (TIMSS) 2007. Tes ini diselenggarakan di bawah payung International Association for Evaluation of Educational Achievement (IEA).

Sesuai dengan tujuan utama diberikannya matematika di sekolah yang satu diantaranya adalah untuk mengembangkan kemampuan pemecahan masalah, maka perlu diterapkan suatu model pembelajaran yang dapat menumbuhkan motivasi, kreativitas dan kemampuan pemahaman siswa dalam memecahkan masalah. Untuk menumbuhkan motivasi, kreativitas dan kemampuan pemecahan siswa pada kegiatan belajar mengajar khususnya dalam melakukan kegiatan matematika, maka harus dikembangkan model pembelajaran matematika yang tidak hanya mentransfer penegatahuan kepada siswa untuk mencerna dan membentuk pengetahuan tetapi juga membantu siswa supaya mampu memecahkan masalah-masalah yang dihadapinya.

Oleh karena itu, dalam kegiatan proses belajar mengajar tentang algoritma saja, tetapi juga berusaha mendorong siswa untuk menerapkan matematika pada pemecahan masalah dan penyidikan untuk menyelesaikan masalah tersebut. "Jika suatu masalah diberikan kepada seorang siswa dan siswa tersebut langsung mengetahui cara menyelesaikannya dengan benar, maka soal tersebut tidak dapat dikatakan sebagai suatu masalah"(Suherman,E.dkk.2003:93). Apabila seorang siswa dihadapkan pada suatu permasalahan dan siswa tersebut tidak tahu secara langsung apa yang harus dilakukan untuk menyelesaikannya, maka dibutuhkan suatu model untuk membantu siswa dalam menyelesaikannya, maka dibutuhkan suatu model untuk membantu siswa dalam menyelesaikan permasalahan tersebut.

Berdasarkan hasil uraian yang telah dikemukakan di atas, maka judul pada penelitian ini adalah Pengaruh Model Pembelajaran Kooperatif Tipe Team Assisted Individualization dan Jigsaw Terhadap Kemampuan Pemecahan Masalah Matematik Siswa MTs Pada Pokok Bahasan Relasi dan Fungsi.

Berdasarkan uraian dari latar belakang maka permasalah pada penelitian ini adalah sebagai berikut:

1. Bagaimana aktivitas guru dan siswa dalam pembelajaran yang mengguakan model kooperatif tipe TAI dan Jigsaw?

2. Apakah terdapat perbedaan peningkatan kemampuan pemecahan masalah matematika siswa antara siswa yang memperoleh pembelajaran dengan model kooperatif tipe TAI, Jigsaw maupun konvensional pada pokok bahasan relasi dan fungsi? 
3. Apakah terdapat perbedaan pencapaian kemampuan pemecahan masalah matematika siswa antara siswa yang memperoleh pembelajaran dengan model kooperatif tipe TAI, Jigsaw maupun konvensional?

4. Apakah terdapat perbedaan sikap siswa terhadap pembelajaran dengan model kooperatif tipe TAI dan Jigsaw?

\section{B. KAJIAN TEORI}

\section{Kemampuan Pemecahan Masalah}

Kemampuan pemecahan masalah didefinisikan oleh Polya (dalam Fitriani, 2006:5) sebagai usaha mencari jalan keluar dari suatu kesulitan, mencapai suatu tujuan yang tidak segera dapat dicapai. Dapat dilihat bahwa memecahkan masalah itu merupakan aktivitas mental yang tinggi. Perlu diketahui bahwa suatu pertanyaan merupakan masalah bergantung pada individu dan waktu. Artinya, suatu pertanyaan merupakan suatu masalah bagi seorang siswa, tetapi mungkin bukan merupakan suatu masalah bagi siswa yang lainnya. Dengan indikator pemecahan masalah sebagai berikut:

a) Mengidentifikasi unsur yang diketahui

b) Merumuskan masalah

c) Menerapkan strategi penyelesaian masalah

d) Memeriksa kembali hasil

\section{Model Pembelajaran Kooperatif Tipe TAI pada Pembelajaran Matematika}

Model pembelajaran adalah sebagai satu diantara pola untuk berinteraksi antara siswa dan guru di dalam kelas yang menyangkut strategi, pendekatan, metode, dan teknik pembelajaran yang diterapkan dalam pelaksanaan kegaiatan belajar mengajar di kelas.

Banyak sekali pakar yang menjelaskan tentang pembelajaran kooperatif tipe TAI, diantaranya, Slavin (2010:189) menyatakan bahwa model pembelajaran kooperatif tipe TAI dimulai sebagai usaha merancang sebuah bentuk penagajaran individual yang biasa menyelesaikan masalah-masalah yang membuat metode pengajaran individual menjadi tidak efektif. Sehingga model pembelajaran kooperatif tipe TAI banyak dijadikan alternatif pembelajaran disetiap satuan pendidikan.

Langkah-langkah pembelajaran kooperatif tipe TAI,yaitu:

a) Pembentukan kelompok yang heterogen, terdiri dari 5-6 orang;

b) Eksplorasi;

c) Pemberian masalah atau soal;

d) Siswa menyelesaikan masalah masing-masing;

e) Klarifikasi guru jika diperlukan;

f) Setiap siswa menyelesaikan tes unit untuk menentukan kriteria kelompok. (Good Team, great team dan super team); 


\section{Model Pembelajaran Kooperatif Tipe Jigsaw}

Dalam penerapan model kooperatif tipe jigsaw secara umum memiliki beberapa langkah-langkah yang dilakukan, satu diantaranya adalah yang diungkapkan oleh Suprijono (2010:89-90) yaitu:

a) Guru membagi materi menjadi beberapa sub bahasan;

b) Siswa dikeompokkan dengan anggota sesuai dengan sub bahasan;

c) Tiap orang dalam tim diberi materi dan tugas yang berbeda;

d) Anggota dari tim yang berbeda dengan penugasan yang sama membentuk kelompok baru (kelompok ahli);

e) Setelah kelompok ahli berdiskusi, tiap anggota kembali kekelompok asal dan menjelaskan kepada anggota kelompok tentang sub bahasan yang mereka kuasai;

f) Tiap tim ahli mempresentasikan hasil diskusi;

g) Pembahasan dari guru;

h) Penutupan dengan memberikan tes individu;

\section{METODE PENELITIAN}

Penelitian ini dilaksanakan menggunakan metode penelitian eksperimen, metode eksperimen yang dilaksanakan menggunakan desain quasi ekperimental (eksperimen semu). Adapun jenis desain dalam penelitian ini berbentuk Nonequivalent (Pretest dan Postest) Control Group Design yang dinyatakan Cresswell (2010:242).Penelitian ini dilaksanakan pada satu diantara MTs. Negeri di Kabupaten Sumedang. Populasi pada penelitian ini adalah seluruh siswa dari satu diantara MTs. Negeri di kota Sumedang dengan sampel terdiri dari 3 kelas. Kelas pertama merupakan kelas eksperimen yang memperoleh pembelajaran matematika menggunakan model TAI, kelas kedua merupakan kelas eksperimen menggunakan model Jigsaw dan kelas ketiga merupakan kelas kontrol yang memperoleh pembelajaran konvensional. Sampel dikelompokkan secara tidak acak, tetapi peneliti menerima keadaan sampel apa adanya dan kelas yang ada telah terbentuk sebelumnya. Penentuan sampel dilakukan dengan teknik purposivesampling dengan pertimbangan bahwa ketiga kelas memiliki karakteristik kemampuan awal matematik yang sama, diajar oleh guru yang sama, mendapatkan fasilitas pembelajaran yang sama dan mereka merupakan kelas awal pada tingkat sekolah menengah pertama yang perlu dikembangkan kemampuannya.

Untuk memperoleh data dalam penelitian ini digunakan instrumen tes kemampuan pemecahan masalahmatematik yang terdiri dari lima soal uraian yang diberikan pada saat pretest dan postest serta lembar observasi aktivitas siswa dan guru terhadap pembelajaran. Untuk pelaksanaan pembelajaran disusun rencana pelaksana pembelajaran dan lembar kerja siswa. Keseluruhan instrumen tersebut telah divalidasi terlebih dalulu. diteskan:

Beberapa soal kemampuan pemecahan masalah matematik yang

1. Jika $f(x)=4 x-5$ untuk $x$ bilangan real, maka tentukan nilai $x$ yang memenuhi persamaan $\mathrm{f}(\mathrm{x})=\mathrm{f}(2 \mathrm{x}-1)$ ?

2. Diketahui dua fungsi yaitu: 
$\mathrm{f}(\mathrm{x})=2-\frac{a}{2} \mathrm{x}$ dan $\mathrm{g}(\mathrm{x})=2-(\mathrm{a}-3) \mathrm{x}$, jika $\mathrm{f}(\mathrm{x})=\mathrm{g}(\mathrm{x})$, cari nilai a kemudian tentukan bentuk fungsi $\mathrm{f}(\mathrm{x})+\mathrm{g}(\mathrm{x})$ ?

Hipotesis:

1. Terdapat perbedaan pencapaian kemampuan pemecahan masalah matematika siswa MTs. X Sumedang yang memperoleh pembelajaran TAI, Jigsaw dan Konvensional.

2. Terdapat perbedaan peningkatan kemampuan pemecahan masalah matematika siswa MTs. X Sumedang yang memeperoleh pembelajaran TAI, Jigsaw dan Konvensional.

3. Terdapat perbedaan sikap siswa yang memperoleh pembelajaran TAI dan Jigsaw.

\section{HASIL PENELITIAN}

Tabel 1

Statistik Deskripsi Data

Hasil Pretes

\begin{tabular}{|c|c|c|c|c|c|}
\hline Kelas & Min. & Maks. & Mean & SD & KKM \\
\hline Kont. & 0 & 68 & 42,2 & 1,5 & \multirow{2}{*}{70} \\
\cline { 1 - 5 } Eks.I & 0 & 70 & 44,8 & 1,7 & \multirow{2}{*}{} \\
\cline { 1 - 4 } Eks.II & 0 & 68 & 41,7 & 1,8 & \\
\hline
\end{tabular}

Tabel 2

Statistik Deskripsi Data

Hasil Postes

\begin{tabular}{|c|c|c|c|c|c|}
\hline Kelas & Min. & Maks. & Mean & SD & KKM \\
\hline Kont. & 42 & 80 & 65 & 9,4 & \multirow{2}{*}{70} \\
\cline { 1 - 4 } Eks.I & 60 & 100 & 76,2 & 8,3 & \multirow{2}{*}{70} \\
\cline { 1 - 4 } Eks.II & 55 & 90 & 75,5 & 7,3 & \\
\hline
\end{tabular}

Berdasarkan kategorisasi data yang terlihat pada tabel di atas, diperoleh rata-rata kemampuan pemecahan masalah matematika siswa pada saat pretes di kelas kontrol 42,2, kelas eksperimen I adalah 44,8, dan kelas eksperimen II adalah 41,7. Rata-rata terbesar untuk nilai pretes yaitu pada kelas ekperimen I dengan nilai rata-ratanya yaitu 44,8. Nilai rata-rata kemampuan pemecahan matematika siswa pada saat postes di kelas kontrol diperoleh rata-ratanya adalah 65, kelas eksperimen I adalah 76,2, dan kelas eskperimen II adalah 75,5. Nilai rata-rata terbesar untuk nilai postes adalah kelas eksperimen I dengan nilai 76,2 .

\section{Tabel 3}

Statistik Deskripsi N-gain Kelas Eksperimen I, Eksperimen II, dan Kontrol

\begin{tabular}{|c|c|c|c|c|c|c|}
\hline \multirow{2}{*}{ Kelas } & \multicolumn{7}{|c|}{ Gain Ternormalisasi } \\
\cline { 2 - 7 } & Min & Mak & Mean & SD & Presetntase & Kategori \\
\hline Kon & 0,0 & 0,75 & 0,36 & 0,18 & 36,8 & Sedang \\
\hline Eks I & 0,14 & 1,00 & 0,53 & 0,21 & 53 & Sedang \\
\hline EksII & 0,09 & 0,85 & 0,55 & 0,16 & 55,1 & Sedang \\
\hline
\end{tabular}


Dari tabel 3 menunjukkan bahwa skor rerata gain ternormalisasi peningkatan kemampuan pemecahan masalah matematika siswa kelas kontrol, kelas eksperimen I, dan kelas eksperimen II tampak berbeda. Skor rerata gain ternormalisasi peningakatan kemampuan pemecahan masalah siswa kelas kontrol adalah 0,368 dari skor ideal dengan standar deviasi 0,185 dan berkategori sedang, sedangkan skor rerata gain ternormalisasi peningkatan kemampuan pemecahan masalah matematika siswa kelas eksperimen adalah 0,530 dari skor ideal dengan standar deviasi 0,217 dan berkategori sedang, dan skor rerata gain ternormalisasi peningakatan kemampuan pemecahan masalah matematika siswa kelas ekperimen II adalah 0,551 dari skor ideal dengan standar deviasi 0,165 dan berkategori sedang.

Karena ketiga kelompok data mempunyai varians homogen dan semua kelompok sampel berdistribusi normal, maka untuk mengetahui ada atau tidaknya perbedaan rerata data ketiga kelas dihitung dengan ANOVA satu jalur.

Tabel 4

ANOVA Satu Jalur

\begin{tabular}{|l|c|c|c|c|c|}
\hline Sumber & $\begin{array}{l}\text { Total } \\
\text { Kuadrat }\end{array}$ & Dk & $\begin{array}{l}\text { Rerata } \\
\text { Kuadrat }\end{array}$ & F & Sig \\
\cline { 1 - 4 } $\begin{array}{l}\text { Antar } \\
\text { Kelompok }\end{array}$ & 0,90 & 2 & 0,45 & \multirow{2}{*}{12,51} & 0,00 \\
\cline { 1 - 4 } $\begin{array}{l}\text { Inter } \\
\text { Kelompok }\end{array}$ & 4,76 & 132 & 0,03 & & \\
\cline { 1 - 5 } Total & 5,66 & 134 & & \\
\hline
\end{tabular}

Berdasarkan perhitungan pada tabel ANOVA satu jalur diperoleh $F_{\text {hitung }}=12,51$ dengan Sig. Atau probabiltas $=0,000$. Hal ini menunjukkan bahwa probabilitas $<0,05$ maka $H_{01}$ ditolak atau terdapat perbedaan peningkatan kemampuan pemecahan masalah matematika siswa pada kelas kontrol, eksperimen I, dan eksperimen II.

Dari data ANOVA satu jalur dapat mengetahui perlakuan mana dari ketiga kelas yang paling efektif dengan melakukan Uji Scheffe data Postes. Yang tersaji pada tabel 5.

\section{Tabel 5}

Uji Scheffe Perbedaan peningkatan Kemampuan Pemecahan Masalah

\begin{tabular}{|c|c|c|c|c|c|}
\hline \multicolumn{2}{|c|}{ Met. Pemb. } & \multirow{2}{*}{$\begin{array}{c}\text { Perb. } \\
\text { Rerata } \\
(\mathrm{I}-\mathrm{J})\end{array}$} & \multirow{2}{*}{ Sig. } & \multicolumn{2}{|c|}{$\begin{array}{c}\text { Interval } \\
\text { Kepercayaan }\end{array}$} \\
\hline I & $\mathbf{J}$ & & & $\begin{array}{l}\text { Batas } \\
\text { Bawah }\end{array}$ & $\begin{array}{l}\text { Batas } \\
\text { Atas }\end{array}$ \\
\hline Eks.1 & Eks.2 & $-0,02$ & 0,87 & $-0,12$ & 0,07 \\
\hline & Kon. & 0,16 & 0,00 & 0,06 & 0,26 \\
\hline Eks.2 & Eks.1 & 0,02 & 0,87 & $-0,07$ & 0,12 \\
\hline & Kon. & 0,18 & 0,00 & 0,08 & 0,28 \\
\hline Kon. & Eks.1 & $-0,16$ & 0,00 & $-0,26$ & $-0,06$ \\
\hline & Eks.2 & $-0,18$ & 0,00 & $-0,28$ & $-0,08$ \\
\hline
\end{tabular}


Untuk melihat perbandingan antara kelas eksperimen I dan kelas ekperimen II dapat dilihat pada kolom Sig, pada kolom tersebut terlihat nilai sig adalah 0,87 karena nilai sig $>0,05$, maka $H_{02}$ diterima. Ini berarti tidak terdapat perbedaan peningkatan kemampuan pemecahan masalah matematika antara kelas eksperimen I dengan siswa kelas eksperimen II atau perbedaan peningkatan kemampaun pemecahan matematikanya sangat tipis.

Selanjutnya untuk melihat perbandingan antara kelas ekperimen I dan kelas kontrol, dapat dilihat pada kolom sig yaitu 0,00. Hal ini berarti sig < 0,05 maka $H_{03}$ ditolak. Ini berarti terdapat perbedaan peningkatan kemampuan pemecahan masalah matematika siswa antara siswa kelas ekeperimen I dengan siswa kelas kontrol.

Untuk melihat perbandingan antara kelas ekperimen II dan kelas kontrol, terlihat bahwa pada kolom Sig adalah 0,00 karena Sig $<0,05$, maka $\mathrm{H}_{04}$ ditolak berarti terdapat perbedaan peningkatan kemampuan pemecahan masalah matematika siswa antara siswa pada kelas ekperimen II dengn siswa pada kelas kontrol.

Berdasarkan uraian tadi dapat dapat diurutkan peringkat dari perbedaan peningkatan kemampuan pemecahan masalah matematika siswa adalah sebagai berikut:

1. Kelas eksperimen II dengan menggunakan metode Jigsaw,

2. Kelas eksperimen I dengan menggunakan metode TAI,

3. Kelas kontrol dengan menggunakan metode konvensional,

Untuk menjawab pertanyaan rumusan masalah ketiga yaitu mengetahui perbedaan pencapaian kemampuan pemecahan masalah matematika siswa antara kelas eksperimen I, eksperimen II dan kelas kontrol, peneliti menggunakan pengolahan data dengan ANOVA satu arah menggunakan SPSS 16. Karena ketiga kelompok data mempunyai varians homogen dan semua kelompok sampel berdistribusi normal, maka untuk mengetahui ada atau tidaknya perbedaan rerata data ketiga kelas dihitung dengan ANOVA satu jalur.

Tabel 6

ANOVA Satu Jalur

\begin{tabular}{|l|c|c|c|c|c|}
\hline Sumber & $\begin{array}{l}\text { Total } \\
\text { Kuadrat }\end{array}$ & Dk & $\begin{array}{l}\text { Rerata } \\
\text { Kuadrat }\end{array}$ & F & Sig \\
\cline { 1 - 5 } $\begin{array}{l}\text { Antar } \\
\text { Kelompok }\end{array}$ & 3566,8 & 2 & 1783,4 & & \\
\cline { 1 - 1 } $\begin{array}{l}\text { Inter } \\
\text { Kelompok }\end{array}$ & 9307,03 & 132 & 70,5 & 25,29 & 0,00 \\
\cline { 1 - 5 } Total & 12873,92 & 134 & & & \\
\hline
\end{tabular}

Berdasarkan perhitungan pada tabel ANOVA satu jalur diperoleh $F_{\text {hitung }}=25,29$ dengan Sig. Atau probabiltas $=0,000$. Hal ini menunjukkan bahwa probabilitas $<0,05$ maka $H_{05}$ ditolak atau dapat dikatakan bahwa terdapat perbedaan pencapaian kemampuan pemecahan masalah matematika siswa pada kelas kontrol, eksperimen I, dan eksperimen II. 
Dari data ANOVA satu jalur dapat mengetahui perlakuan mana dari ketiga kelas yang paling efektif dengan melakukan Uji Scheffe data Postes. Yang tersaji pada tabel 7.

\section{Tabel 7}

Uji Scheffe Perbedaan Pencapaian Kemampuan Pemecahan Masalah

\begin{tabular}{|c|c|c|c|c|c|}
\hline \multicolumn{2}{|c|}{ Met. Pemb. } & \multirow{2}{*}{$\begin{array}{c}\text { Perb. } \\
\text { Rerata } \\
(\mathrm{I}-\mathrm{J})\end{array}$} & \multirow{2}{*}{ Sig. } & \multicolumn{2}{|c|}{$\begin{array}{c}\text { Interval } \\
\text { Kepercayaan }\end{array}$} \\
\hline I & $\mathrm{J}$ & & & $\begin{array}{c}\text { Batas } \\
\text { Bawah }\end{array}$ & $\begin{array}{l}\text { Batas } \\
\text { Atas }\end{array}$ \\
\hline Eks.1 & Eks. 2 & & 0,93 & $-3,72$ & 5,04 \\
\hline & Kon. & 11 , & 0,0 & 6,81 & 15,6 \\
\hline Eks.2 & Eks.1 & $-0,6$ & 0,93 & $-5,04$ & 3,72 \\
\hline & Kon. & 10 & & 6,2 & 14,9 \\
\hline Kon. & Eks.1 & -11 & 0,00 & $-15,6$ & $-6,8$ \\
\hline & Eks. 2 & $-10,5$ & 0,00 & $-14,9$ & $-6,2$ \\
\hline
\end{tabular}

Untuk melihat perbandingan antara kelas eksperimen I dan kelas ekperimen II dapat dilihat pada kolom Sig, pada kolom tersebut terlihat nilai sig adalah 0,93 karena nilai sig $>0,05$, maka $H_{06}$ diterima. Ini berarti tidak terdapat perbedaan pencapaian kemampuan pemecahan masalah matematika antara kelas eksperimen I dengan siswa kelas eksperimen II.

Selanjutnya untuk melihat perbandingan antara kelas ekperimen I dan kelas kontrol, dapat dilihat pada kolom sig yaitu 0,00. Hal ini berarti sig < 0,05 maka $H_{07}$ ditolak. Ini berarti terdapat perbedaan pencapaian kemampuan pemecahan masalah matematika siswa antara siswa kelas ekeperimen I dengan siswa kelas kontrol.

Untuk melihat perbandingan antara kelas ekperimen II dan kelas kontrol, terlihat bahwa pada kolom Sig adalah 0,00 karena Sig < 0,05, maka $H_{08}$ ditolak berarti terdapat perbedaan pencapaian kemampuan pemecahan masalah matematika siswa antara siswa pada kelas ekperimen II dengan siswa pada kelas kontrol.

Untuk menjawab rumusan masalah yang keempat yaitu untuk mengetahui perbedaan sikap siswa yang memperoleh pembelajaran TAI dan pembelajaran Jigsaw, peneliti menggunakan uji t dengan menggunakan perhitungan SPSS 16, sehingga perhitungan mengenai data statistikanya tersaji pada tabel 8 .

\section{Tabel 8}

Statistik Deskripsi Data Skor Skala Sikap

\begin{tabular}{|c|c|c|c|c|}
\hline Kelas & Min. & Mak. & Mean & SD \\
\hline Eks. I & 51 & 73 & 62,5 & 4,9 \\
\hline Eks. II & 53 & 72 & 62,6 & 4,3 \\
\hline
\end{tabular}

Dari tabel 8 menunjukkan skor pada kelas eksperimen I dan kelas eksperimen II tampak berbeda tipis. Karena kedua kelompok data mempunyai varians yang homogen dan kedua kelompok data tersebut berdistribusi normal, maka untuk mengetahui ada atau tidaknya perbedaan sikap siswa 
terhadap pembelajaran menggunakan metode TAI dan metode Jigsaw dihitung menggunakan uji t. Hasil perhitungan disajikan pada tabel 9.

\section{Tabel 9}

\begin{tabular}{|c|c|c|c|c|}
\hline \multicolumn{1}{|c}{ Uji t } \\
\hline $\begin{array}{c}\text { Equal variance } \\
\text { assumsed }\end{array}$ & 0,92 & 0,33 & $-0,09$ & 86 \\
\hline $\begin{array}{c}\text { Equal variance not } \\
\text { assumsed }\end{array}$ & & & $-0,09$ & 84,41 \\
\hline
\end{tabular}

Berdasarkan perhitungan pada tabel 9 uji t terlihat bahwa thitung untuk skor kedua kelompok dengan Equal variance assumsed (diasumsikan kedua varians sama) adalah $t_{\text {hitung }}=-0,091$ dengan Sig atau probabiliti 0,339. Karena sig > 0,05, maka $H_{0}$ diterima atau dapat dikatakan bahwa tidak terdapat perbedaan antara siswa yang belajar dengan menggunakan metode pembelajaran TAI dan metode pembelajaran Jigsaw, atau dapat dikatakan bahwa sikap siswa relatif hampir sama terhadap pembelajaran yang diterapkan dikelas eksperimen I maupun eksperimen II.

\section{E. KESIMPULAN}

Bedasarkan hasil analisis dan pembahasan data penelitian diperoleh beberapa kesimpulan yang terkait dengan hipotesis penelitian yaitu aktivitas siswa dan guru pada kelas eksperimen I, kelas eksperimen II maupun kelas kontrol dilihat dari rata-rata aktivitas pada setiap pertemuan mengalami fluktuasi. Aktivitas siswa ataupun guru selama pembelajaran dilaksanakan sudah cukup sesuai dengan prosedur pembelajaran dalam metode TAI, Jigsaw dan Konvensional. Terjadinya fluktuasi rata-rata aktivitas siswa ataupun guru ini disebabkan oleh kondisi kelas, materi yang dipelajari, dan waktu yang digunakan dalam proses pembelajaran.

Terdapat perbedaan peningkatan kemampuan pemecahan matematika siswa kelas VIII MTs. X Sumedang antara kelas eksperimen I, kelas eksperimen II, dan kelas kontrol. Hal ini dapat dilihat dari perhitungan ANOVA satu jalur dengan menggunakan SPSS 16. Pada perhitungan ANOVA satu jalur diperoleh bahwa nilai $F_{\text {hitung }}=12,514$ dengan probabilitas $=0,000$ untuk $\alpha=5 \%$, sehingga nilai probabilitas $<0,05$ dan diperoleh kesimpulan bahwa terdapat perbedaan peningkatan kemampuan pemecahan masalah matematika siswa antara siswa kelas eksperimen I, kelas eksperimen II, dan kelas kontrol. Diperoleh bahwa kelas eksperimen II adalah kelas yang paling baik peningkatan pemecahan matematikanya, kemudian kelas eksperimen I berada pada urutan kedua dan terakhir kelas kontrol berada pada urutan ketiga dengan memeiliki peningkatan kemampuan pemecahan matematika relatif hampir sama.

Terdapat perbedaan pencapaian kemampuan pemecahan matematika siswa antara kelas eksperimen I, kelas eksperimen II, dan kelas kontrol, hal ini dapat dilihat dari perhitungan ANOVA satu jalur diperoleh bahwa nilai 
$F_{\text {hitung }}=25,294$ dengan probabilitas $=0,000$ untuk $\alpha=5 \%$, sehingga nilai probabilitas $<0,05$ dan diperoleh kesimpulan bahwa terdapat perbedaan pencpaian kemampuan pemecahan masalah matematika siswa antara kelas eksperimen I, kelas eksperimen II, dan kelas kontrol. Dan dapat dilihat juga dari Uji Scheffe bahwa metode pembelajaran yang paling efektif digunakan pada kelas VIII MTs. X Sumedang pada materi pokok relasi dan fungsi adalah metode pembelajaran TAI.

Tidak teradapat perbedaan sikap siswa yang signifikan antara siswa yang memperoleh metode pemeblajaran TAI dengan siswa yang memperoleh metode pembelajaran Jigsaw. Hal ini dapat dilihat dari perhitungan uji $t$ dengan menggunakan SPSS 16. Dengan SPSS 16 diperoleh bahwa nilai sig > 0,05 sehingga diperoleh ksimpulan bahwa sikap siswa terhadap kedua metode pembelajaran terssebut tidak berbeda secara signifikan.

\section{F. DAFTAR PUSTAKA}

Agus,N.A., (2008). Mudah Belajar Matematika I. Jakarta: Pusat Perbukuan Departemen Pendidikan Nasional.

Arikunto,S.(2007). Dasar-dasar Evaluasi Pendidikan. Jakarta: Bumi Aksara.

Creswell, J. W., (2010). Research DesignPendekatan Kualitatif,Kuantitatif, dan Mixed.(Terjemahan) Yogyakarta: Pustaka Pelajar.

Fitriani, A.D. (2006). Upaya Meningkatkan Kemampuan Pemecahan Masalah Matematis Siswa SMA melalui Strategi Means-Ends Analysis. Skripsi FPMIPA UPI Bandung. Tidak Diterbitkan.

Isjoni. (2009). Cooperatif Learning Efektifitas Pembelajaran Kelompok. Bandung. Alfabeta.

Kariadinata, R. (2011). Statistika Penelitian Pendidikan. Bandung: CV. Insan Mandiri.

Mullis, et.al.(2011).TIMSS 2007. International Mathematic Reportt.Boston:TIMSS \& PILPRS International Study Center.

Slavin, R.(2009). Cooperatif Learning. Bandung: Nusa Media.

Suprijono, A.(2010). Cooperatif Learning. Yogyakarta: Pustaka Pelajar.

Suherman, E., dkk. (2005). Common Textbook (Edisi Revisi) Strategi Pembelajaran Matematika Kontemporer. Bandung: JICA UPI. 